\title{
Clumped isotope evidence for Early Jurassic extreme polar warmth and high climate sensitivity
}

\author{
Thomas Letulle ${ }^{1}$, Guillaume Suan ${ }^{1}$, Mathieu Daëron ${ }^{2}$, Mikhail Rogov ${ }^{3}$, Christophe Lécuyer ${ }^{1}$, \\ Arnauld Vinçon-Laugier ${ }^{1}$, Bruno Reynard ${ }^{1}$, Gilles Montagnac ${ }^{1}$, Oleg Lutikov ${ }^{3}$, Jan Schlögl ${ }^{4}$. \\ ${ }^{1}$ Univ Lyon, UCBL, ENSL, UJM, CNRS, LGL-TPE, F-69622, Villeurbanne, France \\ ${ }^{2}$ Laboratoire des Sciences du Climat et de l'Environnement, LSCE/IPSL, CEA-CNRS-UVSQ, Université Paris- \\ Saclay, Orme des Merisiers, F-91191 Gif-sur-Yvette Cedex, France \\ ${ }^{3}$ Geological Institute of Russian Academy of Sciences, Laboratory of Phanerozoic Stratigraphy. \\ ${ }^{4}$ Comenius University, Faculty of Natural Sciences, Department of Geology and Palaeontology, Mlynská dolina \\ G, 84215 Bratislava, Slovak Republik
}

Correspondence to: Thomas Letulle (thomas.letulle@univ-lyon1.fr)

Abstract. Periods of high atmospheric $\mathrm{CO}_{2}$ levels during the Cretaceous-Early Paleogene ( 140 to 33 My ago) were marked by very high polar temperatures and reduced latitudinal gradients relative to the Holocene. These features represent a challenge for most climate models, implying either higher-than-predicted climate sensitivity to atmospheric $\mathrm{CO}_{2}$, or systematic biases or misinterpretations in proxy data. Here, we present a reconstruction of marine temperatures at polar $\left(>80^{\circ}\right)$ and $\operatorname{mid}\left(\sim 40^{\circ}\right)$ paleolatitudes during the Early Jurassic ( 180 My ago) based on the clumped isotope $\left(\Delta_{47}\right)$ and oxygen-isotope $\left(\delta^{18} \mathrm{O}_{c}\right)$ analyses of mildly buried pristine mollusc shells. Reconstructed calcification temperatures range from $\sim 8$ to $\sim 18^{\circ} \mathrm{C}$ in the Toarcian Arctic and from $\sim 24$ to $\sim 28^{\circ} \mathrm{C}$ in Pliensbachian mid-paleolatitudes. These polar temperatures were $\sim 10-20^{\circ} \mathrm{C}$ higher than present along with reduced latitudinal gradients. Reconstructed seawater oxygen isotope values $\left(\delta^{18} \mathrm{O}_{\mathrm{w}}\right)$ of -1.5 to $0.5 \%$ VSMOW and of -5 to $-2.5 \%$ VSMOW at mid and polar paleolatitudes, respectively, point to a significant freshwater contribution in Arctic regions. This highlight the risk of assuming the same $\delta^{18} \mathrm{O}_{\mathrm{sw}}$ value for $\delta^{18} \mathrm{O}$-derived temperature from different oceanic regions. These findings provide critical new constraints for model simulations of Jurassic temperatures and $\delta^{18} \mathrm{O}_{\mathrm{sw}}$ values and suggest that high climate sensitivity is a hallmark of greenhouse climates since at least $180 \mathrm{My}$.

\section{Introduction}

Proxy data indicate that the Cretaceous-Early Paleogene ( 140 to $33 \mathrm{My}$ ago) was characterized by high atmospheric $\mathrm{CO}_{2}$ concentrations, extreme polar warmth and reduced latitudinal temperature gradients (Sluijs et al., 2006; Suan et al., 2017; Evans et al., 2018). Most state-of-the-art climate models hardly reproduce such features, implying either a higher climate sensitivity under greenhouse conditions or systematic biases in proxy data interpretation (Huber and Caballero, 2011; Zhu et al., 2020; Laugié et al., 2020). It remains unclear whether higher climate sensitivity is unique to the Cretaceous-Early Paleogene world or is rather a hallmark of Earth's climate under high atmospheric $\mathrm{pCO}_{2}$. Temperature proxies sensitive to burial, such as molecular or clumpedisotope thermometry, have seldom been applied to older sediments owing to their generally higher thermal maturity (Robinson et al., 2017; Ruebsam et al., 2020; Fernandez et al., 2021). Consequently, current 
temperature estimates for ante-Cretaceous periods are mostly derived from the oxygen isotope composition of marine carbonate fossils $\left(\delta^{18} \mathrm{O}_{\mathrm{c}}\right)$, with well-known limitation related to uncertainties in the past $\delta^{18} \mathrm{O}$ signature of seawater $\left(\delta^{18} \mathrm{O}_{\mathrm{w}}\right)$ (Epstein et al., 1953; Roche et al., 2006; Laugié et al., 2020).

Here, we use carbonate clumped isotope thermometry $\left(\Delta_{47}\right)$, to simultaneously constrain the calcification temperatures and associated $\delta^{18} \mathrm{O}_{\mathrm{w}}$ values of marine carbonate shells collected from Lower Jurassic sedimentary successions with exceptionally shallow to moderate burial depths spanning subtropical to polar paleolatitudes.

45 We compare our results to existing Jurassic to Eocene climate proxy data and simulations and discuss their implications for climate sensitivity under greenhouse conditions.

\section{Geological settings}

\section{$50 \quad 2.1$ Polovinnaya River}

The Polovinnaya River section is located in northern Siberia ( $\left.72^{\circ} 36^{\prime} 05^{\prime \prime} \mathrm{N}, 107^{\circ} 58^{\prime} 52.2^{\prime \prime} \mathrm{E}\right)$, and was located near the north pole during the early Jurassic (Fig. 1). Our bivalve samples come from between 0 and $14 \mathrm{~m}$ in the section and belong to the Toarcian (Suan et al., 2011). This interval consists of silty shale slightly enriched in organic carbon (TOC $\sim .5 \%$ ). Except for localized carbonate concretions, there is no carbonate fraction in the sediment. The studied interval has been previously correlated to the lower Toarcian Serpentinum ammonite zone based on biostratigraphy of foraminifera and dinoflagellate cyst, and lithostratigraphic correlation with other sections of the basin (Suan et al., 2011). This section records very abundant Dacryomya bivalve shells (Fig. S1), an opportunistic suspension-feeder genus tolerant to poorly oxygenated waters, which preferred conditions with weak hydrodynamics (Zakharov and Shurygin, 1978). Few belemnite rostra were also recorded as well isolated fish scales and teeth. The section undergone exceptionally low burial as suggested by the low values of RockEval Pyrolysis $T_{\max }\left(\right.$ mean $\left.=420^{\circ} \mathrm{C}\right)$ previously measured in the host sediments (Suan et al., 2011). Regional stratigraphy from the more distal Anabar area suggest local overburden not exceeding 1000m: a total overburden (Lower Toarcian to Valanginian) of about 380m is recorded in the Anabar River area (Nikitenko et al., 2013) located $200 \mathrm{~km}$ East of the Polovinnaya section, which may be extended to about $1000 \mathrm{~m}$ when adding

65 Valanginian-Cenomanian overburden from the more distal Bol'shoi Begichev islands. Modern local geothermal fluxes are lower than $50 \mathrm{mWm}^{-2}$ (Kerimov et al., 2020), indicative of low geothermal gradient $\left(<25^{\circ} \mathrm{C} / \mathrm{km}\right)$. 


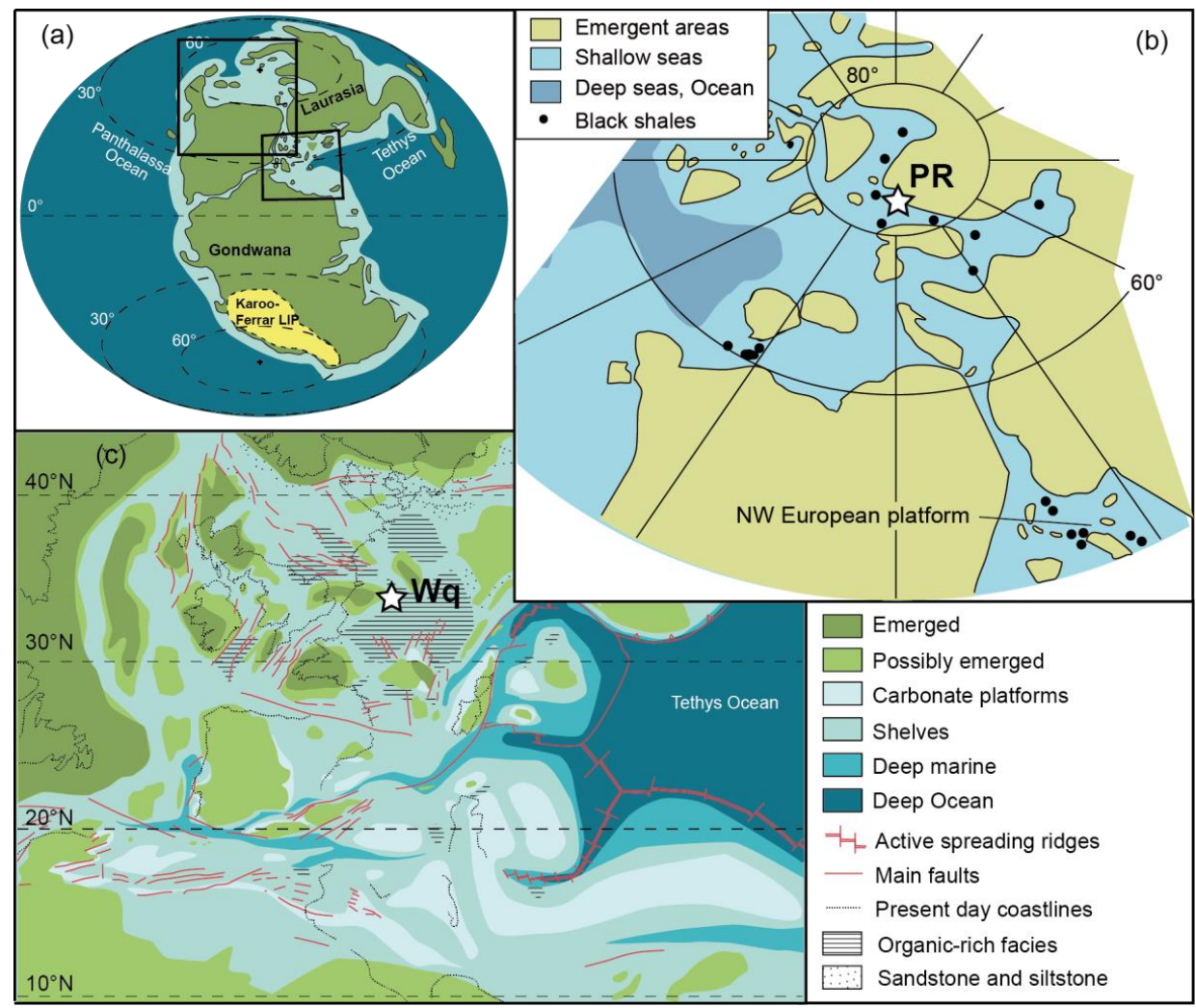

Figure 1. Location of the studied sites with regard to Toarcian (Early Jurassic) geography. (a) Global map modified from Dera et al. (2009). (b) Arctic map modified from Nikitenko and Mickey (2004). (c) Tethyan map modified from Thierry, (2000). Localities: PR = Polovinnaya River; $\mathrm{Wq}=$ Warcq.

\subsection{Warcq}

Samples from north-eastern Paris Basin were collected in 2014 from a temporary road cutting located near Warcq, Ardennes, France (49²5'21.6"N 439'28.8"E). They consist of grey silty claystone with lenses of packed carbonated shell fragments, mainly from a variety of bivalves (Grammatodon, Malletia, Limea, Oxytoma) and few ammonoids (Beaniceras, Aegoceras?, Dactyloceratidae) (Fig. 2). The lithology, fossil preservation and assemblages of the sampled beds is similar to those described by Thuy et al. (2011), from a nearby site of Sedan and dated from the Pliensbachian Davoei zone. The sampled levels are therefore tentatively attributed to the lower Pliensbachian Davoei ammonite zone. Mean $T_{\max }$ values of $425^{\circ} \mathrm{C}$ and maximum burial temperatures near $60^{\circ} \mathrm{C}$ have been reported for Pliensbachian sediments of the NE Paris Basin (Disnar et al., 1996; Blaise et al., 2014). These burial temperatures should be regarded as an upper limit, as the very proximal sampling area near Warcq was repeatedly emerged during the Mesozoic and hence shows a much-thinner Mesozoic cover than these more distal sites (Waterlot et al., 1960). 
https://doi.org/10.5194/cp-2021-79

\begin{tabular}{c} 
Climate \\
of the Past \\
\hline Discussions
\end{tabular}

Preprint. Discussion started: 29 July 2021

(C) Author(s) 2021. CC BY 4.0 License.

(c) (i)

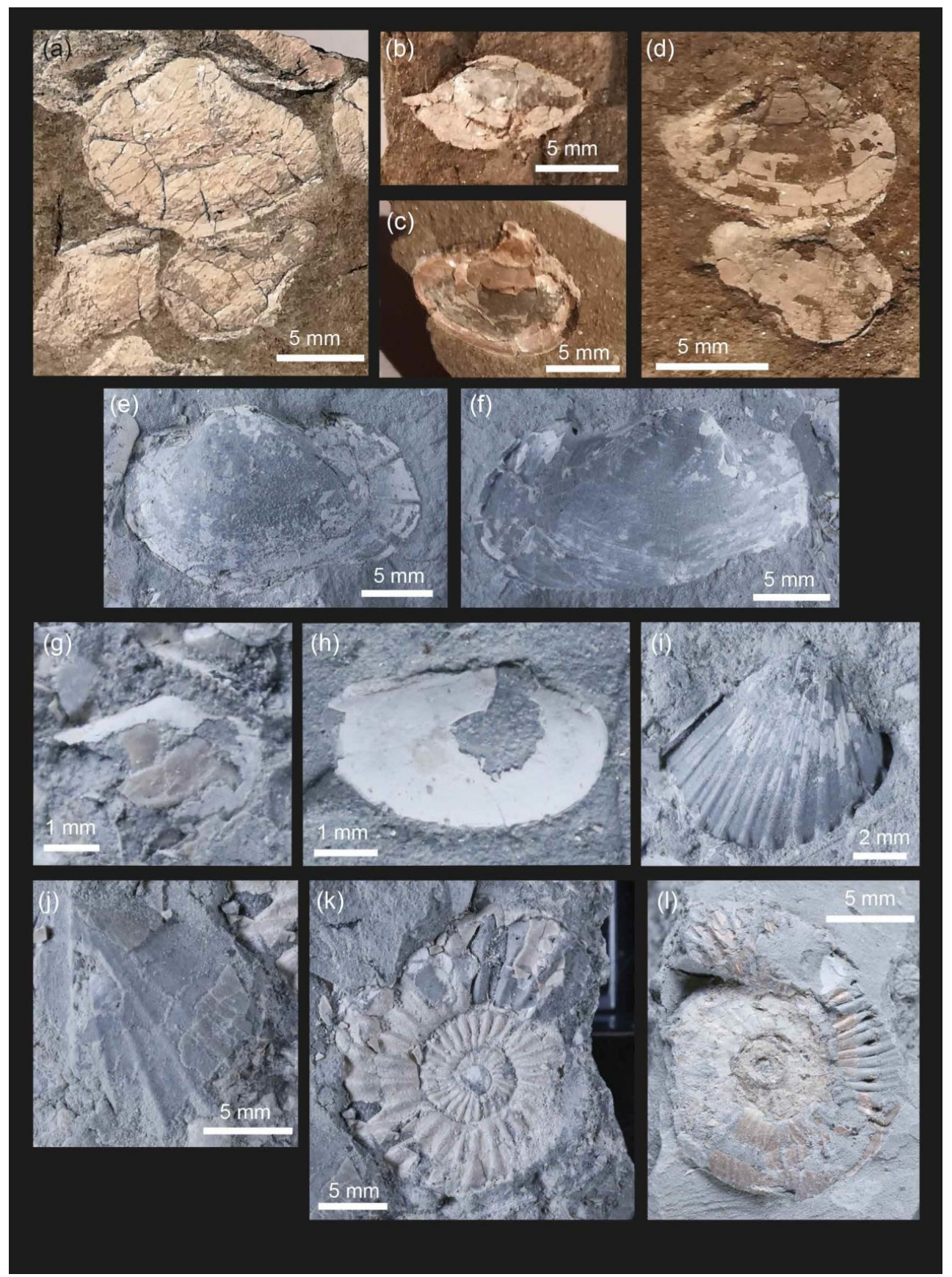

Figure 2. Selected specimens from the sampled successions. (a-d). Polovinnaya River section (Toarcian), (e-

1). Warcq section (Pliensbachian); (a). Dacryomya jacutica, specimen Pol 29; (b). Dacryomya jacutica, specimen

Pol 13; (c-d). Dacryomya jacutica, specimen Pol 5; (e-f). Grammatodon sp., specimen ARD-01; (g-h). Malletia 
sp.; (i). Limea sp., specimen ARD-03; (j). Oxytoma sp.ind. (k). Aegoceras?, specimen ARD 06; (1).

Dactylioceratidae indet., specimen ARD-07.

\section{Material and Methods}

95

\subsection{Sampled material}

The two studied sites present exceptionally rare records of aragonite preservation for the Lower Jurassic interval. Dacryomya shells are the most abundant macrofossil and the unique bivalve genera to occur in the Polovinnaya River section. They are very abundant in the lower part of the section ( 0 to $8 \mathrm{~m})$. They are mainly represented by adult shells, while juveniles are common in only few levels. They appear as $\sim 1 \mathrm{~cm}$ distinct individual or detached valves, sometimes close to each other (Fig. 2). The carbonate shells, often flattened and partially to entirely preserved, are a few millimetres thick but brittle and detached easily from their inner and outer mould. Their cream to white colour contrasts with the dark aspect of the sediment, and few thicker individuals are iridescent. Molluscs shells from Warcq, clearly show a more energetic environment as they mostly appear as packed shell fragments showing a higher taxonomic diversity relative to the other site. Few complete individuals and separated valves can be observed among the debris with their associated mould in or around the remaining shell. Shells are cream to clear white, with some showing iridescence.

The microstructural preservation state and mineralogy of the analysed bivalve and ammonite shells were investigated using a Phenom Pure G2 scanning electron microscope in backscatter mode (BSEM G2) and Raman spectroscopy using an XploRA Raman microscope in Laboratoire de Géologie de Lyon (LGLTPE).

\subsection{Geochemical analysis and data processing}

The remnants of carbonate shells were sampled as a whole using dental tools under a binocular-microscope. A carbonate vein and matrix from the carbonate nodule Pol 29 were also sampled to constrain the geochemistry of this potential diagenetic phase.

The $\Delta_{47}$ and $\delta^{18} \mathrm{O}$ values of 13 samples were measured ( 1 to 5 replicates each) using methods described by (Daëron et al., 2016). Carbonate samples were converted to $\mathrm{CO}_{2}$ by phosphoric acid reaction at $90{ }^{\circ} \mathrm{C}$ in a common, stirred acid bath for 15 minutes. Initial phosphoric acid concentration was $103 \%(1.91 \mathrm{~g} / \mathrm{cm} 3)$ and each batch of acid was used for 7 days. After cryogenic removal of water, the evolved CO2 was helium-flushed at $25 \mathrm{~mL} / \mathrm{mn}$ through a purification column packed with Porapak Q (50/80 mesh, 1 m length, $2.1 \mathrm{~mm}$ ID) and held at $-20{ }^{\circ} \mathrm{C}$, then quantitatively recollected by cryogenic trapping and transferred into an Isoprime 100 dualinlet mass spectrometer equipped with six Faraday collectors (m/z 44-49). Each analysis took about 2.5 hours, during which analyte gas and working reference gas were allowed to flow from matching, $10 \mathrm{~mL}$ reservoirs into the source through deactivated fused silica capillaries (65 cm length, $110 \mu \mathrm{m}$ ID). Every 20 minutes, gas pressures were adjusted to achieve $\mathrm{m} / \mathrm{z}=44$ current of $80 \mathrm{nA}$, with differences between analyte gas and working gas generally below $0.1 \mathrm{nA}$. Pressure-dependent background current corrections were measured 12 times for each analysis. All background measurements from a given session are then used to determine a mass-specific relationship linking background intensity $(\mathrm{Zm})$, total $\mathrm{m} / \mathrm{z}=44$ intensity (I44), and time $(t): \mathrm{Zm}=a+b I 44+c t+$ $d t 2$. Background-corrected ion current ratios ( $\delta 45$ to $\delta 49)$ were converted to $\delta 13 \mathrm{C}, \delta 18 \mathrm{O}$, and "raw" $\Delta 47$ values 
as described by Daëron et al., (2016), using the IUPAC oxygen-17 correction parameters. The isotopic composition $(\delta 13 \mathrm{C}, \delta 18 \mathrm{O})$ of our working reference gas was computed based on the nominal isotopic composition of carbonate standard ETH-3 (Bernasconi et al., 2018) and an oxygen-18 acid fractionation factor of 1.00813 (Kim et al., 2007). Raw $\Delta 47$ values were then converted to the I-CDES $\Delta 47$ reference frame by comparison with four "ETH" carbonate standards (Bernasconi et al., 2021) using a pooled regression approach (Daëron, 2021). Full analytical errors are derived from the external reproducibility of unknowns and standards $(\mathrm{Nf}=89)$ and conservatively account for the uncertainties in raw $\Delta 47$ measurements as well as those associated with the conversion to the "absolute" $\Delta 47$ reference frame. Complementary $\delta^{13} \mathrm{C}$ and $\delta^{18} \mathrm{O}$ analyses of the smallest Arctic shells were performed at LGLTPE, using a Multiprep ${ }^{\mathrm{TM}}$ automated sampler coupled to a dual-inlet GV Isoprime ${ }^{\mathrm{TM}}$ mass spectrometer. Samples were reacted with anhydrous phosphoric acid at $90^{\circ} \mathrm{C}$. Duplicated samples were adjusted to the international references NIST NBS 18 and NBS 19 as well as in-house standard Carrara Marble. Since 2019 overall reproducibility of the in-house standard Carrara Marble are \pm 0.082 for $\delta^{18} \mathrm{O}(2 \mathrm{SE}, \mathrm{n}=441)$ and $\pm 0.057 \%$ for $\delta 13 \mathrm{C}(2 \mathrm{SE}, \mathrm{n}=441)$ with mean $\delta^{18} \mathrm{O}$ and $\delta^{13} \mathrm{C}$ values respectively of $-1.041 \%$ and $+2.025 \%$ (V-PDB). All carbonate isotopic values $\left(\delta^{13} \mathrm{C}, \delta^{18} \mathrm{O}_{\mathrm{c}}\right)$ are reported in \%o VPDB.

Clumped isotope temperatures were computed based on the I-CDES calibration of (Anderson et al., 2021). Temperature uncertainties correspond to the fully-propagated $95 \%$ confidence intervals from $\Delta_{47}$ measurements of each sample (Daëron, 2021), neglecting the much smaller uncertainties in the calibration. The $\delta^{18} \mathrm{O}$ values from aragonite samples were adjusted considering the different phosphoric acid fractionation factors for calcite and aragonite (Kim et al., 2007). The $\delta^{18} \mathrm{O}_{\mathrm{w}}$ values relative to VSMOW was estimated using $\Delta_{47}$-derived temperatures and the equations of Grossman and Ku (1986) and Kim and O’Neil (1997) for mollusc shells and calcite vein respectively.

Paleolatitude of the studied sites was computed using the online paleolatitude calculator paleolatitude.org (van Hinsbergen et al., 2015) computed with the model of Torsvik et al. (2012).

\section{Results}

The SEM observations of shell fragments of Dacryomya jacutica revealed well preserved sheet nacreous microstructures underlying a prismatic layer we interpret as the outer shell layer (Fig. 3). All Raman spectra gathered from Dacryomya jacutica shells confirm that the original aragonite mineralogy is preserved. Mollusk shells from Warcq showing an aragonite mineralogy revealed microstructures similar to those observed in Dacryomya jacutica, the main differences being that sheet nacreous structures of the studied ammonite shell (ARD-05) shows thinner tablets than those of bivalve shells (Fig. 3). Both SEM and Raman data indicate that the sample ARD-03 (bivalve fragment) is in calcite, showing a darker colour and no iridescence, with a much simpler and massive structure observed in SEM (Fig. 3).

Reconstructed $\Delta 47$ temperatures range from $8.5 \pm 5.2^{\circ} \mathrm{C}$ to $17.7 \pm 3.4^{\circ} \mathrm{C}$ for Siberian bivalves, from $24.1 \pm 4.38^{\circ} \mathrm{C}$ to 27.6 $\pm 3.3{ }^{\circ} \mathrm{C}$ for molluscs from NE France, while for the fracture-infilling calcite vein from Siberia a temperature of $31.1 \pm 4.8{ }^{\circ} \mathrm{C}$ is inferred. Mean $\delta^{18} \mathrm{O}_{\mathrm{c}}$ values are $-2.73 \pm 0.71 \%$ ( $1 \mathrm{SD}, \mathrm{n}=31$, Max=0.36, Min=-5.08\%o) for Siberian bivalves and $-14.21 \pm 0.02 \%$ for the fracture-infilling calcite vein, and $-2.07 \pm 0.86 \%$ o $(1 \mathrm{SD}, \mathrm{n}=4$, $\mathrm{Max}=-0.84 \%$, Min=-2.54\%o) for molluscs from NE France. The carbon isotope values $\left(\delta^{13} \mathrm{C}\right)$ range from $0.37 \%$ to $2.82 \%$ in the selected molluscs from Warcq, from $3.47 \%$ to $5.09 \%$ in the Russian Arctic bivalves, and reach 
values down to $-21.43 \%$ and $-4.67 \%$ for carbonate nodule matrix and the embedded bivalve shells (sample POL-29) respectively.

The calculated $\delta^{18} \mathrm{O}_{\mathrm{w}}$ values range from $0.5 \pm 0.7 \%$ to $-1.5 \pm 1.0 \%$ in molluscs from NE France, from $4.88 \pm 1.20 \%$ to $-2.52 \pm 0.78 \%$ in Siberian bivalves. A much lower value of $-10.6 \pm 0.9 \%$ is obtained for the

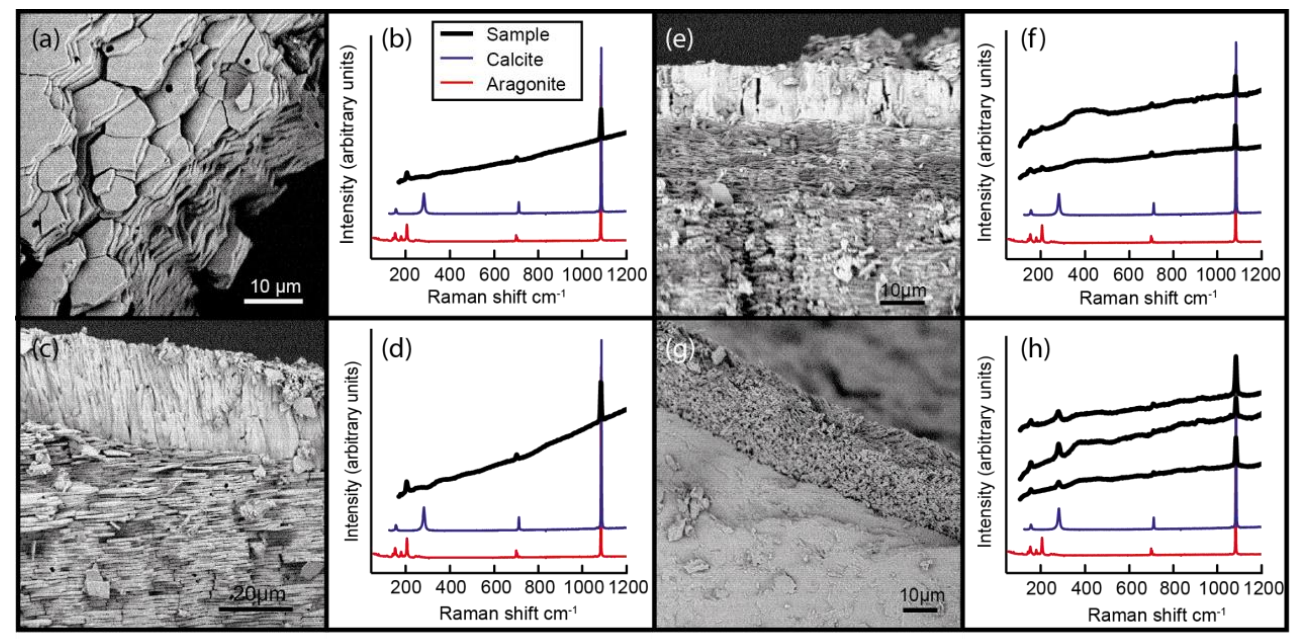

Figure 3. SEM images and Raman spectra for a selection of samples. a, c, e and g SEM images form samples POL-8, POL-12, ARD-05 and ARD-03 respectively. b, d, f and g Raman spectra from samples POL-8, POL-12, ARD-05 and ARD-03 compared to the reference spectra of calcite and aragonite.

\section{Discussion}

\subsection{Sample preservation}

The SEM and Raman observations reveal that the analysed mollusc shells from both sites retain pristine aragonite mineralogy and microstructures with no evidence of recrystallization (Fig. 3). Despite their aragonite mineralogy, the Dacryomya shells from sample Pol-29 record unusually low $\delta^{13} \mathrm{C}$ that are $\sim 8 \%$ lower than the other Dacryomya shells analysed from the same succession. The carbonate matrix of the nodule where these shells are embedded also records a very low $\delta^{13} \mathrm{C}$ value $\left(-21.43 \%\right.$ ) but a $\delta^{18} \mathrm{O}$ value within the range of the bivalve shells. We therefore attribute the extremely low $\delta^{13} \mathrm{C}$ values of bivalves shells of this level to an early diagenetic phase resulting in the formation of carbonate nodules derived from respiratory $\mathrm{CO}_{2}$ that locally altered the bivalve shells geochemistry.

Organic matter maturity, mineralogical and sedimentological data all imply exceptionally shallow burial depth $(<1 \mathrm{~km})$ for the samples investigated here. Maximum burial temperature $\left(\mathrm{T}_{\text {burial }}\right)$ remained well below the commonly assumed minimum temperature $\left(80-120^{\circ} \mathrm{C}\right)$ of solid-state reordering of C-O bonds at geological timescales (Henkes et al., 2014; Stolper and Eiler, 2015; Hemingway and Henkes, 2021). The exceptional preservation of aragonite nacreous sheet microstructures in these samples imply minimal amounts of fluid circulation and recrystallization, if any. Exchange between fluid inclusions in mollusc shells and the surrounding 
carbonate minerals was recently suggested as an alternative process that may alter the clumped isotope signature of biogenic carbonates without substantially affecting the stable isotope signature of the shell nor its mineralogy (Nooitgedacht et al., 2021). In their heating experiments, these exchanges resulted in a significant decrease of the $\Delta_{47}$ value of the bivalve shells compared to the original shell, and a minor $\left(\sim 0.1 \%\right.$ o decrease in $\delta^{18} \mathrm{O}$ of the heated shell. We cannot exclude that this process has altered the fossils studied here even at low temperature, nor do we have evidence that it occurred. The $\Delta_{47}$ temperature of $31.1 \pm 4.8^{\circ} \mathrm{C}$ for the fracture-infilling calcite vein in Arctic Russia is significantly higher than those inferred from bivalves and is consistent with a formation depth $<1 \mathrm{~km}$ assuming a geothermal gradient of $25^{\circ} \mathrm{C} / \mathrm{km}$. The reconstructed $\delta^{18} \mathrm{O}_{\mathrm{w}}$ value of $-10.7 \pm 0.9 \%$ for this calcite vein is also substantially lower than those inferred from associated bivalves, consistent with a late-phase meteoric source for the mineralizing fluid.

5.2 Evidence for extreme warmth and reduced salinity in the Arctic during the Toarcian Oceanic Anoxic Event

Bivalve shells record a marked rise in $\delta^{13} \mathrm{C}$ along the section up to $\sim 5 \%$ that parallels that recorded by organic carbon $\delta^{13} \mathrm{C}$ data (Fig. 4; Suan et al., 2011). These results strengthen the correlation of the corresponding part of the succession with the rising limb of the positive carbon isotope excursion commonly used to characterise the termination of T-OAE interval in coeval sites of Europe and North Africa (Jenkyns and Clayton, 1986; Suan et al., 2010; Krencker et al., 2014; Ullmann et al., 2020; Baghli et al., 2020). Bivalve shells $\delta^{18} \mathrm{O}_{c}$, however, show no stratigraphic trend as opposed to brachiopod shell T-OAE records from mid-latitudes (Suan et al., 2010; Krencker et al., 2014; Ullmann et al., 2020; Baghli et al., 2020). Our $\Delta_{47}$ results yield polar temperatures ranging from $8.5 \pm 5.2$ to $17.7 \pm 3.4{ }^{\circ} \mathrm{C}$. As it occurs with most $\Delta_{47}$-derived temperature datasets, the relatively large uncertainties of the present estimates of Siberian SST hamper the identification of distinctive stratigraphic trends.

Bivalve shell growth can be highly variable during the animal life (Schöne, 2008), making any paleoenvironmental record derived from bivalve shell either incomplete (because of growth cessation) or at least biased towards the period of maximum growth rate. Shell growth rate can be controlled by both environmental parameters (Temperature, salinity, food availability ...), biological processes such as spawning and ontogeny (Schöne, 2008). One major aspect of shell growth that may bias the geochemical signal data is seasonal shell growth-cessation. In modern high latitude bivalves, seasonal shell growth-cessation generally occurs during the winter, triggered by low temperatures or low food availability (Peck et al., 2000; Vihtakari et al., 2016; Killam and Clapham, 2018).

230 It appears likely that food availability declined markedly during the Early Jurassic polar night, which would have certainly led to winter growth cessation in the analysed Dacryomya shells. In the present-day Nucula annulata, an aragonite bivalve with similar ecology to the analysed Dacryomya jacutica, growth cessation occurs in winter and during spawning at peak local temperatures, its average $\delta^{18} \mathrm{O}_{\mathrm{c}}$ hence records late spring to early fall SST (Craig, 1994). By contrast, growth band $\delta^{18} \mathrm{O}_{\mathrm{c}}$ offers evidence for summertime-only growth cessation in highlatitude Eocene bivalves from Antarctica, with inferred winter SST of $11.1 \pm 0.6$ and summer SST of $17.6 \pm 1.3^{\circ} \mathrm{C}$ (Buick and Ivany, 2004; Douglas et al., 2014) very close to our maximal and minimum SST estimates of the Toarcian Arctic. A comparable seasonal $\delta^{18} \mathrm{O}_{\mathrm{c}}$ record could not be generated from our Russian Arctic material owing to the very small size of the available Dacryomya shells (1 to $2 \mathrm{~cm}$ ). In any case, the temperate data from 
NE France should be minimally affected by seasonal biases as shell precipitation occurs more continuously throughout the year in modern temperate molluscs (Killam and Clapham, 2018). Besides, both sites were deposited in near shore environments at very shallow depths likely not exceeding a few tens of meters (Thuy et al., 2011; Suan et al., 2011). Although bivalves from both sections record temperatures near the sea bottom that were likely slightly cooler than the sea surface, the difference should not exceed a few degrees. We therefore conservatively interpret the reconstructed temperatures as reflecting polar warm-season SST (summer; $\mathrm{SST}_{\mathrm{PWS}}$ ) in Arctic Russia and low latitude annual SST in NE France. These $\mathrm{SST}_{\mathrm{PWs}}$ for the T-OAE are still $10-20^{\circ} \mathrm{C}$ higher than present-day $\mathrm{SST}_{\mathrm{PwS}}$ (Fig. 5).

The reconstructed polar $\delta^{18} \mathrm{O}_{\mathrm{w}}$ values ranging from $-4.9 \pm 1.2$ to $-2.5 \pm 0.8 \%$ during the T-OAE are significantly lower than the value of $-1 \%$ expected for an ice-free world mean open ocean (Shackleton and Kennett, 1975). These results imply a substantial freshwater contribution to the studied basin during the T-OAE, probably resulting from coastal runoff at this relatively proximal site, as evidenced from abundant terrestrial organic matter (Suan et al., 2011). High temperatures and reduced salinity are in broad agreement with paleontological evidence for warm and humid temperate conditions during the T-OAE interval in Arctic Siberia (Rogov et al., 2019). Arctic coast salinity can be inferred from $\Delta_{47}$-derived $\delta^{18} \mathrm{O}_{\mathrm{w}}$ with reasonable assumptions of local $\delta^{18} \mathrm{O}$ of precipitations and runoff $\left(\delta^{18} \mathrm{O}_{\mathrm{p}}\right)$. Higher polar temperatures should have produced higher $\delta^{18} \mathrm{O}_{\mathrm{p}}$ than those prevailing today (Rozanski et al., 1992), a hypothesis supported by terrestrial plants $n$-alkanes hydrogen isotopes and paleosol siderite $\Delta_{47}$ data indicating Early Eocene $\delta^{18} \mathrm{O}_{\mathrm{p}}$ of -10 to $-15 \%$ (Pagani et al., 2006; van Dijk et al., 2020). Assuming a similar range of $\delta^{18} \mathrm{O}_{\mathrm{p}}$ values in the Early Jurassic Arctic, and a global mean ocean with a salinity of $34.5 \%$ and a $\delta^{18} \mathrm{O}_{w}$ of $-1 \%$, mass balance calculations indicate mean salinity of $23.9 \pm 2.9 \%$ o $(1 \sigma, \mathrm{n}=8)$ and $27.7 \pm 1.8 \%(1 \sigma, n=8)$ with $\delta^{18} \mathrm{O}_{\mathrm{p}}$ of -10 and $-15 \%$, respectively (see Supplementary Data). These estimates point towards brackish waters at Polovinnaya River during the Toarcian, consistent with the fossil assemblages of the succession that includes abundant terrestrial organic matter and wood debris, marine to brackish elements such as abundant dinoflagellate cysts, benthic foraminifera (preserved as organic linings and agglutinate forms) but rarer typically marine elements that are only represented by a few belemnite rostra and unidentifiable ammonite internal moulds (Suan et al., 2011). Such values are also comparable to the salinity of 28\%o estimated using a fully coupled ocean-atmosphere model for the Toarcian (Dera and Donnadieu, 2012), although the Arctic temperature obtained by the same model are in strong disagreement with our data (Fig. 5). Such observations should be replicated around the Arctic realm to test whether the brackish environment evidenced here is of local or more regional nature. 


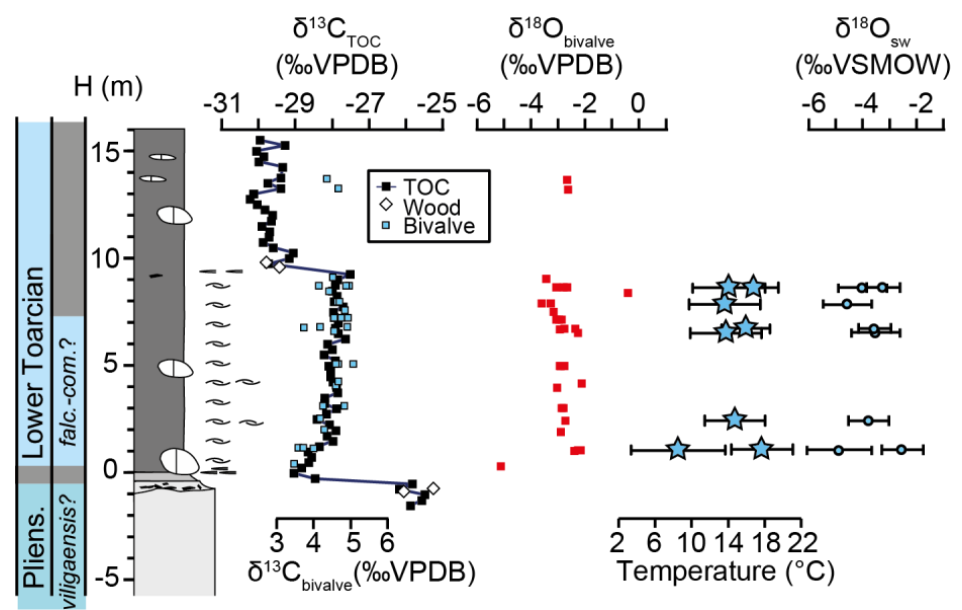

Figure 4. Geochemical record of the T-OAE at Polovinnaya River, Arctic Siberia. Stratigraphy and organic carbon isotope ( $\left.\delta^{13} \mathrm{C}_{\mathrm{TOC}}\right)$ data from Suan et al. (2011). The analysed bivalve samples all belong to the species Dacryomya jacutica. $\Delta_{47}$-derived temperatures were computed using the equation of Anderson et al. (2021). $\delta^{18} \mathrm{O}_{\mathrm{w}}$ was calculated using the oxygen isotope fractionation equation of Grossman and $\mathrm{Ku}$ (1986).

\subsection{Early Jurassic latitudinal temperature and $\delta^{18} \mathrm{O}_{\mathrm{w}}$ gradients}

The mid paleolatitude SST reconstructed by our new clumped isotope data are in good agreement with recent Sinemurian-Pliensbachian and Toarcian $\mathrm{TEX}_{86}{ }^{\mathrm{H}}$ data pointing to summer SST $20-30^{\circ} \mathrm{C}$ at slightly lower paleolatitudes (Robinson et al., 2017; Ruebsam et al., 2020). Considering the scarcity of other Early Jurassic temperature proxy-data, model-based SST and $\delta^{18} \mathrm{O}_{\mathrm{w}}$ estimates, we extend the comparison to SST and $\delta^{18} \mathrm{O}_{\mathrm{w}}$ estimates based on various proxy-data and published Earth system simulations for other Jurassic to Eocene intervals (Fig. 5; Supplement). This compilation shows that $\Delta_{47}$ SST from NE France agree with most previous $\mathrm{TEX}_{86}{ }^{\mathrm{H}}$ and $\Delta_{47} \mathrm{SST}$ for the Jurassic-Eocene interval, with values $>5^{\circ} \mathrm{C}$ higher than present-day SST. This comparison also shows that the Maastrichtian was characterized by substantially lower $\Delta_{47}$ SST, in line with independent evidence for global cooling during this interval (O’Brien et al., 2017; Pucéat et al., 2003), although many $\Delta_{47}$ records from this stage come from the Western Interior Seaway (WIS) where temperatures were likely influenced by specific regional patterns, such as southward influence of arctic water or significant freshwater contribution in the basin (Coulson et al., 2011; Petersen et al., 2016). This compilation also reveals lower SSTs near $50^{\circ} \mathrm{N}$ in the Callovo-Oxfordian. Russian Arctic SST are very close to Campanian-Maastrichtian and Early Eocene TEX ${ }_{86}{ }^{\mathrm{H}}$-derived SST (Jenkyns et al., 2004; Sluijs et al., 2020) and Early Eocene bioclimatic SST (Suan et al., 2017) from the Arctic (Fig. 5). The $\Delta_{47}$ data presented herein suggest a decrease in mean SST of $0.26 \pm 0.05^{\circ} \mathrm{Cper}^{\circ}$ of latitude, i.e., a reduction of the latitudinal SST gradient of $32 \pm 10 \%$ relative to present, consistent with the most conservative Early Eocene estimates (Evans et al., 2018).

Our $\Delta_{47}$ SST for the Lower-Jurassic can be compared to published results from Earth System models that simulate past intervals of global warmth to discuss model-data discrepancies. Proxy-data indicate an atmospheric $\mathrm{pCO}_{2}$ of $1000 \pm 500$ ppmv during the Early Jurassic, with maximum values of $1750 \pm 500$ ppmv, i.e., $6 \mathrm{x}$ preindustrial levels (PIL), during the T-OAE (McElwain et al., 2005; Li et al., 2020). Earth system models run at 6x PIL for Early Jurassic (Dera and Donnadieu, 2012) or Cretaceous-Eocene paleogeography almost invariably 
produce lower SST than those inferred from our $\Delta_{47}$ data, with a maximum model-data discrepancy of $>15^{\circ} \mathrm{C}$ at high latitudes (Fig. 5). To achieve such polar warmth, the Eocene CCSM3 simulations require 16x PIL, more than twice that indicated by Lower Jurassic and Eocene proxy data (Huber and Caballero, 2011). Reconstructed SST of $14.4 \pm 2.8^{\circ} \mathrm{C}$ near the North Pole during the T-OAE, however, correspond to the maximum monthly temperatures simulated by the Turonian IPSL-CM5A2 model near the North Pole at 4x PIL (Laugié et al., 2020). The hypothesis of shell growth restricted to warmest month in the analysed Toarcian Arctic bivalves, however, remains questionable given the evidence for summertime-only growth cessation in Eocene bivalves from Antarctica (Buick and Ivany, 2004). Finally, Arctic SST as high as $15-20^{\circ} \mathrm{C}$ are successfully achieved in the Eocene CESM1.2 CAM5 at 6 to 9x PIL (Zhu et al., 2020), in which climate sensitivity increases with rising $\mathrm{CO}_{2}$ due to low-altitude cloud albedo feedbacks and improved radiative parameterization. As this model produces an increase in climate sensitivity with $\mathrm{CO}_{2}$ in both Eocene and modern conditions, our results thus support the growing body of evidence that the amplitude of the future anthropogenic warming may be underestimated by conventional state-of-the-art models.

The reconstruction of $\delta^{18} \mathrm{O}_{\mathrm{w}}$ values using proxy data provides a complementary aspect to assess model capabilities, as this indicator is sensitive to both climate parameters (moisture, humidity and temperatures) and paleogeography. Our mid-latitude $\delta^{18} \mathrm{O}_{\mathrm{w}}$ are broadly similar to those reconstructed using marine turtle bones $\delta^{18} \mathrm{O}_{\mathrm{PO} 4}$ and $\Delta_{47}$ data from Jurassic to Eocene bivalves, ammonites, foraminifera, as well as belemnites (Fig. 5).

315 As for temperatures, regional processes in the Western Interior Seaway explains the mid latitude very low $\delta^{18} \mathrm{O}_{\mathrm{w}}$ indicated by most late Cretaceous $\Delta_{47}$ data (Petersen et al., 2016).

We are aware of only few Earth-system $\delta^{18} \mathrm{O}_{\mathrm{w}}$ simulations for the interval considered here (Zhou et al., 2008; Tindall et al., 2010; Zhu et al., 2020), hence limiting model-data comparisons. The higher freshwater contribution near high-latitude landmasses of the Northern Hemisphere in both models produced lower $\delta^{18} \mathrm{O}_{\mathrm{w}}$ that are broadly consistent with previous and our proxy data (Fig. 5). This good agreement, however, might be partly fortuitous, as proxy data suggest SST much higher than those produced by both models (Fig. 5). As mentioned above, such higher-than-predicted polar warmth would have substantially increased high-latitude $\delta^{18} \mathrm{O}_{\mathrm{p}}$, so that higher runoff would be required to reproduce the magnitude of the poleward drop in $\delta^{18} \mathrm{O}_{\mathrm{w}}$ indicated by proxy data. This highlights the usefulness, in future models of past greenhouse climates, to systematically provide $\delta^{18} \mathrm{O}_{\mathrm{w}}$ predictions so that $\delta^{18} \mathrm{O}_{\mathrm{w}}$ estimates derived from $\Delta 47$ data may serve as a constraint on Earth system models. 

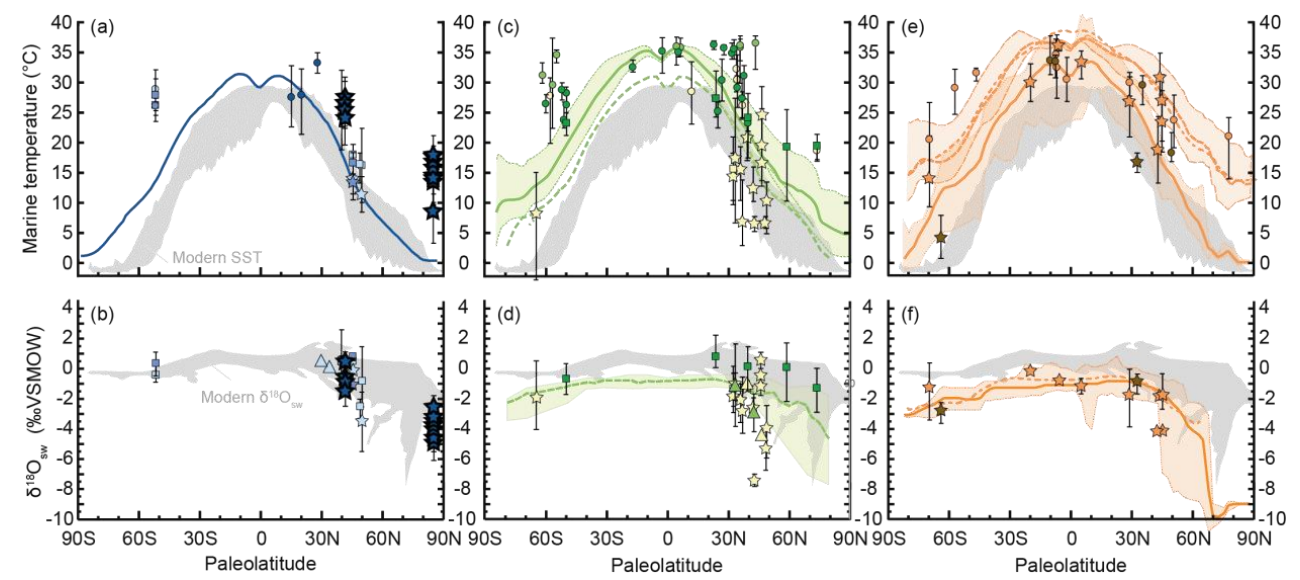

Proxy data: $\star$ Bivalve, ammonite \& foram $\Delta_{47} \quad$ - Belemnite $\Delta_{47} \quad \cdot \mathrm{TEX}_{86}{ }^{\mathrm{H}} \quad \boldsymbol{\Delta}$ Marine turtle $\delta^{18} \mathrm{O}$

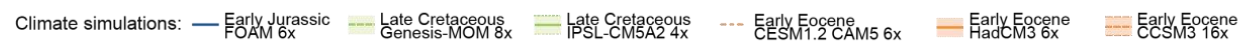

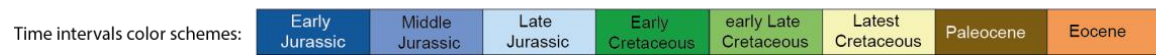

Figure 5. Comparison of the new (bold outline) reconstructed Early Jurassic SST and $\delta^{18} \mathbf{O}_{\text {sw }}$ with Jurassic-Eocene proxy-based reconstructions (thin outline) and Earth system simulations. Proxy-model comparison of SST and $\delta 18$ Osw are shown for the Jurassic (a, b), the Cretaceous (c, d) and the Early Paleogene (e, f). Marker colour in proxy data shows sample age (see key). Results of Earth system simulations are shown as annual averages (bold lines) and summer and winter seasonal averages (colour shading). See supplement for references used in this compilation.

\section{Conclusion}

The clumped isotope compositions of pristine, minimally buried, marine molluscs shells yield SST $>25^{\circ} \mathrm{C}$ at mid-latitudes during the early Pliensbachian and SST $>10^{\circ} \mathrm{C}$ at polar paleolatitudes during the T-OAE. The reconstructed $\delta^{18} \mathrm{O}_{\mathrm{w}}$ values point to higher freshwater contribution toward Arctic regions, illustrating the dangers of assuming a fixed global $\delta^{18} \mathrm{O}_{\mathrm{w}}$ value for $\delta^{18} \mathrm{O}$-derived temperature reconstructions. Although further work should clarify the influence of seasonal changes in the recorded SST values at polar sites, these results strengthen a growing body of evidence for higher climate sensitivity under high atmospheric $\mathrm{CO}_{2}$ conditions and suggest that this higher sensitivity is a general feature of greenhouse climates since at least $180 \mathrm{Ma}$.

\section{Data availability}

Detailed data supporting this study are available in the supplementary material. Raw data are available on request to the author.

\section{Author contribution}

TL and GS designed the study and led the writing in close cooperation with CL, MR and MD. MR and GS participated to the field work and collected the samples. TL prepared and sampled the shell material for geochemistry and performed the SEM observations. MR, JS and OL identified the fossils. MD and TL performed the clumped isotope analyses and data processing. AV-L and TL performed the stable isotopes 


\section{Competing interest}

The authors declare that they have no conflict of interest.

\section{Acknowledgments}

15015. We thank Ghislaine Broillet for her help with SEM analyses, and Ophélie Lodyga for help with Raman analyses.

\section{References}

365 Anderson, N. T., Kelson, J. R., Kele, S., Daëron, M., Bonifacie, M., Horita, J., Mackey, T. J., John, C. M., Kluge, T., Petschnig, P., Jost, A. B., Huntington, K. W., Bernasconi, S. M., and Bergmann, K. D.: A unified clumped isotope thermometer calibration $\left(0.5-1100^{\circ} \mathrm{C}\right)$ using carbonate-based standardization, Geophys Res Lett, https://doi.org/10.1029/2020GL092069, 2021.

Baghli, H., Mattioli, E., Spangenberg, J. E., Bensalah, M., Arnaud-Godet, F., Pittet, B., and Suan, G.: Early Jurassic climatic trends in the south-Tethyan margin, 15, 2020.

Bernasconi, S. M., Müller, I. A., Bergmann, K. D., Breitenbach, S. F. M., Fernandez, A., Hodell, D. A., Jaggi, M., Meckler, A. N., Millan, I., and Ziegler, M.: Reducing Uncertainties in Carbonate Clumped Isotope Analysis Through Consistent Carbonate-Based Standardization, Geochem. Geophys. Geosyst., 19, 2895-2914, https://doi.org/10.1029/2017GC007385, 2018.

375 Bernasconi, S. M., Daëron, M., Bergmann, K. D., Bonifacie, M., Meckler, A. N., Affek, H. P., Anderson, N., Bajnai, D., Barkan, E., Beverly, E., Blamart, D., Burgener, L., Calmels, D., Chaduteau, C., Clog, M., Davidheiser-Kroll, B., Davies, A., Dux, F., Eiler, J., Elliott, B., Fetrow, A. C., Fiebig, J., Goldberg, S., Hermoso, M., Huntington, K. W., Hyland, E., Ingalls, M., Jaggi, M., John, C. M., Jost, A. B., Katz, S., Kelson, J., Kluge, T., Kocken, I. J., Laskar, A., Leutert, T. J., Liang, D., Lucarelli, J., 380 Mackey, T. J., Mangenot, X., Meinicke, N., Modestou, S. E., Müller, I. A., Murray, S., Neary, A., Packard, N., Passey, B. H., Pelletier, E., Petersen, S., Piasecki, A., Schauer, A., Snell, K. E., Swart, P. K., Tripati, A., Upadhyay, D., Vennemann, T., Winkelstern, I., Yarian, D., Yoshida, N., Zhang, N., and Ziegler, M.: InterCarb: A Community Effort to Improve Interlaboratory Standardization of the Carbonate Clumped Isotope Thermometer Using Carbonate Standards, Geochem Geophys Geosyst, 22, https://doi.org/10.1029/2020GC009588, 2021.

Blaise, T., Barbarand, J., Kars, M., Ploquin, F., Aubourg, C., Brigaud, B., Cathelineau, M., El Albani, A., Gautheron, C., Izart, A., Janots, D., Michels, R., Pagel, M., Pozzi, J.-P., Boiron, M.-C., and Landrein, P.: Reconstruction of low temperature $\left(<100^{\circ} \mathrm{C}\right)$ burial in sedimentary basins: A comparison of geothermometer in the intracontinental Paris Basin, Marine and Petroleum Geology, 53, 71-87, https://doi.org/10.1016/j.marpetgeo.2013.08.019, 2014.

Buick, D. P. and Ivany, L. C.: 100 years in the dark: Extreme longevity of Eocene bivalves from Antarctica, Geology, 32, 921-924, https://doi.org/10.1130/G20796.1, 2004.

Coulson, A. B., Kohn, M. J., and Barrick, R. E.: Isotopic evaluation of ocean circulation in the Late Cretaceous North American seaway, Nature Geosci, 4, 852-855, https://doi.org/10.1038/ngeo1312, 2011. 
Craig, N.: Growth of the bivalve Nucula annulata in nutrient-enriched environments, Mar. Ecol. Prog. Ser., 104, 77-90, https://doi.org/10.3354/meps104077, 1994.

Daëron, M.: Full Propagation of Analytical Uncertainties in $\Delta_{47}$ Measurements, Geochem Geophys Geosyst, 22, https://doi.org/10.1029/2020GC009592, 2021.

Daëron, M., Blamart, D., Peral, M., and Affek, H. P.: Absolute isotopic abundance ratios and the accuracy of $\Delta 47$ measurements, Chemical Geology, 442, 83-96, https://doi.org/10.1016/j.chemgeo.2016.08.014, 2016.

Dera, G. and Donnadieu, Y.: Modeling evidences for global warming, Arctic seawater freshening, and sluggish oceanic circulation during the Early Toarcian anoxic event, Paleoceanography, 27, n/a-n/a, https://doi.org/10.1029/2012PA002283, 2012.

Dera, G., Pucéat, E., Pellenard, P., Neige, P., Delsate, D., Joachimski, M. M., Reisberg, L., and Martinez, M.: Water mass exchange and variations in seawater temperature in the NW Tethys during the Early Jurassic: Evidence from neodymium and oxygen isotopes of fish teeth and belemnites, Earth and Planetary Science Letters, 286, 198-207, https://doi.org/10.1016/j.epsl.2009.06.027, 2009.

410 van Dijk, J., Fernandez, A., Bernasconi, S. M., Caves Rugenstein, J. K., Passey, S. R., and White, T.: Spatial pattern of super-greenhouse warmth controlled by elevated specific humidity, Nature Geoscience, 13, 739-744, https://doi.org/10.1038/s41561-020-00648-2, 2020.

Disnar, J. R., Le Strat, P., Farjanel, G., and Fikri, A.: Sédimentation de la matière organique dans le nord-est du Bassin de Paris: conséquences sur le dépôt des argilites carbonées du Toarcien inférieur 415 (Organic matter sedimentation in the northeast of the Paris Basin: consequences on the deposition of the lower toarcian black shales), Chemical Geology, 131, 15-35, https://doi.org/10.1016/00092541(96)00021-6, 1996.

Douglas, P. M. J., Affek, H. P., Ivany, L. C., Houben, A. J. P., Sijp, W. P., Sluijs, A., Schouten, S., and Pagani, M.: Pronounced zonal heterogeneity in Eocene southern high-latitude sea surface temperatures, Proceedings of the National Academy of Sciences, 111, 6582-6587, https://doi.org/10.1073/pnas.1321441111, 2014.

Epstein, S., Buchsbaum, R., Lowenstam, H. A., and Urey, H. C.: Revised carbonate-water isotopic temperature scale, Geol Soc America Bull, 64, 1315, https://doi.org/10.1130/00167606(1953)64[1315:RCITS]2.0.CO;2, 1953.

425 Evans, D., Sagoo, N., Renema, W., Cotton, L. J., Müller, W., Todd, J. A., Saraswati, P. K., Stassen, P., Ziegler, M., Pearson, P. N., Valdes, P. J., and Affek, H. P.: Eocene greenhouse climate revealed by coupled clumped isotope-Mg/Ca thermometry, Proc Natl Acad Sci USA, 115, 1174-1179, https://doi.org/10.1073/pnas.1714744115, 2018.

Fernandez, A., Korte, C., Ullmann, C. V., Looser, N., Wohlwend, S., and Bernasconi, S. M.: 430 Reconstructing the magnitude of Early Toarcian (Jurassic) warming using the reordered clumped isotope compositions of belemnites, 293, 308-327, https://doi.org/10.1016/j.gca.2020.10.005, 2021.

Grossman, E. L. and Ku, T.-L.: Oxygen and carbon isotope fractionation in biogenic aragonite: temperature effects, 59, 59-74, https://doi.org/10.1016/0168-9622(86)90057-6, 1986.

Hemingway, J. D. and Henkes, G. A.: A disordered kinetic model for clumped isotope bond 
Henkes, G. A., Passey, B. H., Grossman, E. L., Shenton, B. J., Pérez-Huerta, A., and Yancey, T. E.: Temperature limits for preservation of primary calcite clumped isotope paleotemperatures, Geochimica et Cosmochimica Acta, 139, 362-382, https://doi.org/10.1016/j.gca.2014.04.040, 2014.

van Hinsbergen, D. J. J., de Groot, L. V., van Schaik, S. J., Spakman, W., Bijl, P. K., Sluijs, A., Langereis, C. G., and Brinkhuis, H.: A Paleolatitude Calculator for Paleoclimate Studies, PLOS ONE, 10, e0126946, https://doi.org/10.1371/journal.pone.0126946, 2015.

Huber, M. and Caballero, R.: The early Eocene equable climate problem revisited, 7, 603-633, https://doi.org/10.5194/cp-7-603-2011, 2011.

Jenkyns, H. C. and Clayton, C. J.: Black shales and carbon isotopes in pelagic sediments from the Tethyan Lower Jurassic, Sedimentology, 33, 87-106, https://doi.org/10.1111/j.13653091.1986.tb00746.x, 1986.

Jenkyns, H. C., Forster, A., Schouten, S., and Sinninghe Damsté, J. S.: High temperatures in the Late Cretaceous Arctic Ocean, Nature, 432, 888-892, https://doi.org/10.1038/nature03143, 2004.

450 Kerimov, V. Yu., Shcherbina, Yu. V., and Ivanov, A. A.: Formation conditions and evolution of oil and gas source strata of the Laptev sea shelf ore and gas province, Izvestiya Vysshikh Uchebnykh Zavedeniy. Geologiya i Razvedka, 46-59, https://doi.org/10.32454/0016-7762-2020-63-3-46-59, 2020 .

Killam, D. E. and Clapham, M. E.: Identifying the ticks of bivalve shellL clocks: seasonal growth in relation to temperature and food supply, 33, 228-236, https://doi.org/10.2110/palo.2017.072, 2018.

Kim, S.-T. and O'Neil, J. R.: Equilibrium and nonequilibrium oxygen isotope effects in synthetic carbonates, Geochimica et Cosmochimica Acta, 61, 3461-3475, https://doi.org/10.1016/S00167037(97)00169-5, 1997.

Kim, S.-T., Mucci, A., and Taylor, B. E.: Phosphoric acid fractionation factors for calcite and aragonite between 25 and $75^{\circ} \mathrm{C}$ : Revisited, Chemical Geology, 246, 135-146, https://doi.org/10.1016/j.chemgeo.2007.08.005, 2007.

Krencker, F. N., Bodin, S., Hoffmann, R., Suan, G., Mattioli, E., Kabiri, L., Föllmi, K. B., and Immenhauser, A.: The middle Toarcian cold snap: Trigger of mass extinction and carbonate factory demise, 15, 2014.

465 Laugié, M., Donnadieu, Y., Ladant, J.-B., Green, J. A. M., Bopp, L., and Raisson, F.: Stripping back the modern to reveal the Cenomanian-Turonian climate and temperature gradient underneath, Clim. Past, 16, 953-971, https://doi.org/10.5194/cp-16-953-2020, 2020.

Li, X., Wang, J., Rasbury, T., Zhou, M., Wei, Z., and Zhang, C.: Early Jurassic climate and atmospheric $\mathrm{CO}_{2}$ concentration in the Sichuan paleobasin, southwestern China, 16, 2055-2074,

470 https://doi.org/10.5194/cp-16-2055-2020, 2020.

McElwain, J. C., Wade-Murphy, J., and Hesselbo, S. P.: Changes in carbon dioxide during an oceanic anoxic event linked to intrusion into Gondwana coals, Nature, 435, 479-482, https://doi.org/10.1038/nature03618, 2005.

Nikitenko, B. L. and Mickey, M. B.: Foraminifera and ostracodes across the Pliensbachian-Toarcian boundary in the Arctice Realm (stratigraphy, palaeobiogeography and biofacies), 230, 137-174, https://doi.org/10.1144/GSL.SP.2004.230.01.08, 2004.

Nikitenko, B. L., Shurygin, B. N., Knyazev, V. G., Meledina, S. V., Dzyuba, O. S., Lebedeva, N. K., Peshchevitskaya, E. B., Glinskikh, L. A., Goryacheva, A. A., and Khafaeva, S. N.: Jurassic and 
Cretaceous stratigraphy of the Anabar area (Arctic Siberia, Laptev Sea coast) and the Boreal zonal standard, Russian Geology and Geophysics, 54, 808-837, https://doi.org/10.1016/j.rgg.2013.07.005, 2013.

Nooitgedacht, C. W., van der Lubbe, H. J. L., Ziegler, M., and Staudigel, P. T.: Internal water facilitates thermal resetting of clumped isotopes in biogenic aragonite, Geochem Geophys Geosyst, https://doi.org/10.1029/2021GC009730, 2021.

485 O’Brien, C. L., Robinson, S. A., Pancost, R. D., Sinninghe Damsté, J. S., Schouten, S., Lunt, D. J., Alsenz, H., Bornemann, A., Bottini, C., Brassell, S. C., Farnsworth, A., Forster, A., Huber, B. T., Inglis, G. N., Jenkyns, H. C., Linnert, C., Littler, K., Markwick, P., McAnena, A., Mutterlose, J., Naafs, B. D. A., Püttmann, W., Sluijs, A., van Helmond, N. A. G. M., Vellekoop, J., Wagner, T., and Wrobel, N. E.: Cretaceous sea-surface temperature evolution: Constraints from TEX 86 and planktonic foraminiferal oxygen isotopes, Earth-Science Reviews, 172, 224-247, https://doi.org/10.1016/j.earscirev.2017.07.012, 2017.

Pagani, M., Pedentchouk, N., Huber, M., Sluijs, A., Schouten, S., Brinkhuis, H., Damste, J. S. S., and Dickens, G. R.: Arctic hydrology during global warming at the Palaeocene/Eocene thermal maximum, 442, 671-675, https://doi.org/10.1038/nature05043, 2006.

495 Peck, L. S., Colman, J. G., and Murray, A. W. A.: Growth and tissue mass cycles in the infaunal bivalve Yoldia eightsi at Signy Island, Antarctica, Polar Biology, 23, 420-428, https://doi.org/10.1007/s003000050463, 2000.

Petersen, S. V., Tabor, C. R., Lohmann, K. C., Poulsen, C. J., Meyer, K. W., Carpenter, S. J., Erickson, J. M., Matsunaga, K. K. S., Smith, S. Y., and Sheldon, N. D.: Temperature and salinity of 500 the Late Cretaceous Western Interior Seaway, Geology, 44, 903-906, https://doi.org/10.1130/G38311.1, 2016.

Pucéat, E., Lécuyer, C., Sheppard, S. M. F., Dromart, G., Reboulet, S., and Grandjean, P.: Thermal evolution of Cretaceous Tethyan marine waters inferred from oxygen isotope composition of fish tooth enamels, Paleoceanography, 18, n/a-n/a, https://doi.org/10.1029/2002PA000823, 2003.

505 Robinson, S. A., Ruhl, M., Astley, D. L., Naafs, B. D. A., Farnsworth, A. J., Bown, P. R., Jenkyns, H. C., Lunt, D. J., O’Brien, C., Pancost, R. D., and Markwick, P. J.: Early Jurassic North Atlantic seasurface temperatures from TEX 86 palaeothermometry, Sedimentology, 64, 215-230, https://doi.org/10.1111/sed.12321, 2017.

Roche, D. M., Donnadieu, Y., Pucéat, E., and Paillard, D.: Effect of changes in $\delta^{18} \mathrm{O}$ content of the surface ocean on estimated sea surface temperatures in past warm climate, Paleoceanography, 21, n/an/a, https://doi.org/10.1029/2005PA001220, 2006.

Rogov, M. A., Zverkov, N. G., Zakharov, V. A., and Arkhangelsky, M. S.: Marine Reptiles and Climates of the Jurassic and Cretaceous of Siberia, Stratigr. Geol. Correl., 27, 398-423, https://doi.org/10.1134/S0869593819040051, 2019.

515 Rozanski, K., Araguas-Araguas, L., and Gonfiantini, R.: Relation Between Long-Term Trends of Oxygen-18 Isotope Composition of Precipitation and Climate, Science, 258, 981-985, https://doi.org/10.1126/science.258.5084.981, 1992.

Ruebsam, W., Reolid, M., Sabatino, N., Masetti, D., and Schwark, L.: Molecular paleothermometry of the early Toarcian climate perturbation, 195, 103351, https://doi.org/10.1016/j.gloplacha.2020.103351, 2020 . 
Schöne, B. R.: The curse of physiology — challenges and opportunities in the interpretation of geochemical data from mollusk shells, Geo-Mar Lett, 28, 269-285, https://doi.org/10.1007/s00367008-0114-6, 2008.

Shackleton, N. J. and Kennett, J. P.: Paleotemperature history of the Cenozoic and the initiation of Antarctic glaciation: oxygen and carbon isotope analyses in DSDP Sites 277,279, and 281, 29, 743756, 1975.

Sluijs, A., Schouten, S., Pagani, M., Woltering, M., Brinkhuis, H., Damsté, J. S. S., Dickens, G. R., Huber, M., Reichart, G.-J., Stein, R., Matthiessen, J., Lourens, L. J., Pedentchouk, N., Backman, J., Moran, K., and the Expedition 302 Scientists: Subtropical Arctic Ocean temperatures during the

530 Palaeocene/Eocene thermal maximum, Nature, 441, 610-613, https://doi.org/10.1038/nature04668, 2006.

Sluijs, A., Frieling, J., Inglis, G. N., Nierop, K. G. J., Peterse, F., Sangiorgi, F., and Schouten, S.: Late Paleocene - early Eocene Arctic Ocean Sea Surface Temperatures; reassessing biomarker paleothermometry at Lomonosov Ridge, Proxy Use-Development-Validation/Marine Archives/Cenozoic, https://doi.org/10.5194/cp-2020-13, 2020.

Stolper, D. A. and Eiler, J. M.: The kinetics of solid-state isotope-exchange reactions for clumped isotopes: A study of inorganic calcites and apatites from natural and experimental samples, 315, 363411, https://doi.org/10.2475/05.2015.01, 2015.

Suan, G., Mattioli, E., Pittet, B., Lécuyer, C., Suchéras-Marx, B., Duarte, L. V., Philippe, M., Reggiani, L., and Martineau, F.: Secular environmental precursors to Early Toarcian (Jurassic) extreme climate changes, $11,2010$.

Suan, G., Nikitenko, B. L., Rogov, M. A., Baudin, F., Spangenberg, J. E., Knyazev, V. G., Glinskikh, L. A., Goryacheva, A. A., Adatte, T., Riding, J. B., Föllmi, K. B., Pittet, B., Mattioli, E., and Lécuyer, C.: Polar record of Early Jurassic massive carbon injection, Earth and Planetary Science Letters, 312,

545 102-113, https://doi.org/10.1016/j.eps1.2011.09.050, 2011.

Suan, G., Popescu, S.-M., Suc, J.-P., Schnyder, J., Fauquette, S., Baudin, F., Yoon, D., Piepjohn, K., Sobolev, N. N., and Labrousse, L.: Subtropical climate conditions and mangrove growth in Arctic Siberia during the early Eocene, 45, 539-542, https://doi.org/10.1130/G38547.1, 2017.

Thierry, J.: Middle Toarcian map. 8, in: Dercourt, J., Gaetani, M., Vrielynck, B., Barrier, E., BijuDuval, B., Brunet, M.F. ... Sandulescu, M. (Eds.), Altlas Peri-Tethys Palaeogeographical Maps., CCGM/CGMW, Paris, 61-70, 2000.

Thuy, B., Gale, A. S., and Reich, M.: A new echinoderm Lagerstätte from the Pliensbachian (Early Jurassic) of the French Ardennes, Swiss J Palaeontol, 130, 173-185, https://doi.org/10.1007/s13358010-0015-y, 2011.

555 Tindall, J., Flecker, R., Valdes, P., Schmidt, D. N., Markwick, P., and Harris, J.: Modelling the oxygen isotope distribution of ancient seawater using a coupled ocean-atmosphere GCM: Implications for reconstructing early Eocene climate, Earth and Planetary Science Letters, 292, 265-273, https://doi.org/10.1016/j.epsl.2009.12.049, 2010.

Torsvik, T. H., Van der Voo, R., Preeden, U., Mac Niocaill, C., Steinberger, B., Doubrovine, P. V., 560 van Hinsbergen, D. J. J., Domeier, M., Gaina, C., Tohver, E., Meert, J. G., McCausland, P. J. A., and Cocks, L. R. M.: Phanerozoic polar wander, palaeogeography and dynamics, Earth-Science Reviews, 114, 325-368, https://doi.org/10.1016/j.earscirev.2012.06.007, 2012. 
Ullmann, C. V., Boyle, R., Duarte, L. V., Hesselbo, S. P., Kasemann, S. A., Klein, T., Lenton, T. M., Piazza, V., and Aberhan, M.: Warm afterglow from the Toarcian Oceanic Anoxic Event drives the success of deep-adapted brachiopods, Sci Rep, 10, 6549, https://doi.org/10.1038/s41598-020-63487-6, 2020.

Vihtakari, M., Renaud, P. E., Clarke, L. J., Whitehouse, M. J., Hop, H., Carroll, M. L., and Ambrose, W. G.: Decoding the oxygen isotope signal for seasonal growth patterns in Arctic bivalves, Palaeogeography, Palaeoclimatology, Palaeoecology, 446, 263-283, https://doi.org/10.1016/j.palaeo.2016.01.008, 2016.

Waterlot, G., Bonte, A., and Destombes, J.-P.: Carte géologique de la France à 1:50 000. [68], Renwez, France, 1960.

Zakharov, V. A. and Shurygin, B. N.: Biogeography, facies and stratigraphy of the Middle Jurassic of Soviet Arctic (by bivalve molluscs), 352, 1-206, 1978.

575 Zhou, J., Poulsen, C. J., Pollard, D., and White, T. S.: Simulation of modern and middle Cretaceous marine $\delta^{18} \mathrm{O}$ with an ocean-atmosphere general circulation model: Modern, mid-Cretaceous seawater $\delta^{18}$ O, Paleoceanography, 23, n/a-n/a, https://doi.org/10.1029/2008PA001596, 2008.

Zhu, J., Poulsen, C. J., Otto-Bliesner, B. L., Liu, Z., Brady, E. C., and Noone, D. C.: Simulation of early Eocene water isotopes using an Earth system model and its implication for past climate reconstruction, Earth and Planetary Science Letters, 537, 116164, https://doi.org/10.1016/j.epsl.2020.116164, 2020. 